\title{
Spatio-Temporal Assessment of Water Quality in Douala IV Municipality, Cameroon
}

\author{
Mary Lum Fonteh Niba ${ }^{*}$, Theophile Fonkou ${ }^{2}$, Cornelius Mbifung Lambi ${ }^{3}$ \\ ${ }^{1}$ Department of Geography, Higher Teacher Training College, The University of Bamenda, Bambili, Cameroon \\ ${ }^{2}$ Department of Plant Biology, Faculty of Science, University of Dschang, Dschang, Cameroon \\ ${ }^{3}$ Department of Geography, Faculty of Social and Management Sciences, University of Buea, Buea, Cameroon \\ Email: *mariefontehniba3@gmail.com
}

How to cite this paper: Niba, M.L.F., Fonkou, T. and Lambi, C.M. (2019) Spatio-Temporal Assessment of Water Quality in Douala IV Municipality, Cameroon. Journal of Water Resource and Protection, 11, 1441-1461.

https://doi.org/10.4236/jwarp.2019.1112084

Received: August 19, 2019

Accepted: December 3, 2019

Published: December 6, 2019

Copyright $\odot 2019$ by author(s) and Scientific Research Publishing Inc. This work is licensed under the Creative Commons Attribution International License (CC BY 4.0).

http://creativecommons.org/licenses/by/4.0/

\section{Open Access}

\begin{abstract}
The study analysed the spatial and temporal contamination levels of fresh water resources by saline intrusion in the Douala coastal area. Water samples were collected from 19 stations. 3 stations were selected from the mangrove area and 16 stations were selected from the rest of the area partitioned into four transects (coastal transect, inner transect 1, inner transect 2 and inner transect 3). Sampling was done repeatedly during the wet and dry seasons. They were analyzed for physico-chemical parameters according to the American Public Health Association methods. Geostatistical analysis was used in mapping the water properties. Considerable levels of actual electrical conductivity values (208.91 to 660.63 and 45 to $7540 \mu \mathrm{S} / \mathrm{cm}$ for the wet and dry seasons, respectively); calcium ( 0.06 to 85 and 4 to $256 \mathrm{mg} / \mathrm{L}$ for the wet and dry seasons, respectively); sulphate (0 to 103 and 0 to $99 \mathrm{mg} / \mathrm{L}$ for the wet and dry seasons) and total dissolved solids (15.79 to 1467 and 20 to $3750 \mathrm{mg} / \mathrm{L}$ for the wet and dry seasons, respectively) were observed for ground water in the study area based on spatio-temporal assessment. From the output grid, it could be deduced that the south eastern region had a hint of salt water intrusion (SWI) contamination of fresh water resources with actual value highs of electrical conductivity (1790 and $820 \mu \mathrm{S} / \mathrm{cm})$ for the dry and wet seasons, respectively. Calcium highs ( 140 and $16 \mathrm{mg} / \mathrm{L}$ ) for the dry and wet seasons were obtained at the central part of the study area. The spatial distribution of calcium highs extends from the central zone of the study area in the dry season and the south eastern zone in the wet season. The southern region is more vulnerable to contamination by calcium ions during this season. An up to date scope for surveillance monitoring and forecasting regarding the deterioration of coastal aquifers is recommended. Modelling of aquifers shifts for the coastal zone should be instituted as a means of ensuring efficient fresh water resources evaluation and utilization. An in-depth study of the geo-
\end{abstract}


chemical characteristics of ground water of the coastal zone could determine factors that most significantly impact on fresh water resource quality.

\section{Keywords}

Spatio-Temporal, Assessment, Fresh Water Resources, Water Quality, Geostatistics, Douala IV Municipality, Cameroon

\section{Introduction}

About $50 \%$ of the Cameroonian population does not have access to safe drinking water [1]. This is especially so for the Douala metropolis which houses about $70 \%$ of the nation's industries. Industrial expansion and human population growth in the Douala metropolis are putting natural resources including water under a lot of pressure. Despite the abundance of water resources in the area, the supply of adequate quantities of drinking water is still an elusive target. Consequently, big industries (breweries, textile, soap factories, agrochemical plants and so on) are going for ground water to meet their needs for quantity and quality.

It seems more than likely that the industrial use of groundwater may represent a far more apparent threat to the groundwater quality (salt water intrusion (SWI)) in comparism of an increase of sea water temperature (may be an effect of global warming). In addition, predictions of increasing rise in the sea level in the area as in [2] and [3] and associated hazards in the region may exacerbate the problem of ground water quality in the long run. Reference [4] indicates that salinization of the water resources could also be due to the formation of large piezometric draw-down cones resulting from the increasing extraction of ground water and this could accelerate SWI by reversing the hydraulic gradients into the aquifers. More so, SWI into coastal aquifers, rivers and estuaries is one of the impacts that coastal residents will face because of global warming as a result of thermal expansion of oceans [5] [6] [7]. Still, this threat is mainly linked to an "over-outtake" of ground water. The described problem of "Draw-down cones" was apparent for Copenhagen many years ago. The main threat was the "over-outtake" of groundwater.

Therefore, the regular monitoring of the quality of these ground water resources is important since industrial processes which are driving the economy of the nation depend on these resources. Regular monitoring is also important to protect the health of the inhabitants as some of them also depend on this ground water for their livelihoods.

The regularity of monitoring is necessitated by the temporal variation in the quality of ground water due to the influence by other factors like changes in rainfall pattern, sea level rise, flooding due to storm surge, salt water intrusion, rising water table and wetland loss. Understanding these temporal variations in 
water quality has important practical implications for water resource management; it could ensure their rational exploitation for water supply in the area. The aim of this paper is to investigate ground water quality for the dry and wet seasons through the temporal and spatial integration methods as well as R-plots. R-plots are graphs that connect a series of points by drawing line segments between them. They are ordered in one of their coordinates, usually the $\mathrm{x}$-coordinate value. They help in identifying trends in data. Geostatistical techniques were further used for the graphical representation of data trends.

\section{Materials and Methods}

\subsection{Study Area and Survey Design of Water Data Sampling Points}

Four coastal zone routes in the Douala IV district of Bonassama were selected to check SWI into open wells between November 2014 to May 2015 for the dry and raining season. Three sampling periods were carried out for the dry and the wet seasons, respectively. The locations and altitudes of selected sample sites were determined on the field using a Garmin GPS 60 CX. This enabled the location of the coordinates to produce sample location maps and the routes and 16 of the sampling stations with their location are given in [8].

\subsection{Collection and Analysis of Water Samples}

Water was drawn from the open wells using drawing buckets tied with ropes. Each water sample was collected into a collector after thorough rinsing with the water to be sampled. Water from the collector was filled into $500 \mathrm{~mL}$ capacity plastic bottles and preserved to avoid evaporation. The samples were stored in ice-chest containers at about $4^{\circ} \mathrm{C}$ for about six hours prior to laboratory analysis to exclude microbial activity and unwanted chemical activity.

Temperature, electrical conductivity (EC), dissolved oxygen (DO), $\mathrm{pH}$ salinity and TDS were measured directly on the field using a DO probe and an $\mathrm{EC} / \mathrm{pH} /$ temperature meter.

Chemical parameters were determined as per standard APHA methods as in [9]. The chemical analyses were performed in the Laboratory for Waste Water Research of the Faculty of Science in the University of Yaounde 1, Cameroon. The total hardness of calcium $\left(\mathrm{Ca}^{2+}\right)$ and magnesium $\left(\mathrm{Mg}^{2+}\right)$ was determined by using the EDTA complexometric titration method; chloride $\left(\mathrm{Cl}^{-}\right)$by the argentometric method; nitrate, sulphate and phosphate measurements were done using ion chromatography on a Dionex ICS-900. Reference [10], indicates that the charge balance calculated should be within the acceptable limit of $\pm 5 \%$. Sodium $\left(\mathrm{Na}^{+}\right)$and potassium $\left(\mathrm{K}^{+}\right)$were analysed by the flame photometric method; salinity was measured using $\mathrm{HACH}$ salinity meter. Bicarbonate $\left(\mathrm{HCO}_{3}^{-}\right)$was measured through titration by adding $0.02-\mathrm{M} \mathrm{HCl}$ solution to the sample while stirring until the endpoint marked by a $\mathrm{pH}$ of 4.5 , was obtained.

To get a clear grasp of the spatio-temporal chemical composition of water resources in the Douala IV area, water samples were subjected to geostatistical 
analysis. The geostatistics was used to describe spatial patterns and interpolates values for locations where samples were not taken. The analysis was used to estimate pollutant levels in order to determine pollutant concentrations in ground water. This was to indicate if they pose a threat to human health and environmental health as well as warranting remediation [11].

Kriging which is one of the interpolation methods helps to predict values for cells in a raster from a limited number of sample data points used. Hence when dispersed sample input point locations are selected, predicted values (height, concentration of water parameters) can be assigned to all other locations. Kriging results were, therefore, employed with the assumption that the distance or direction between sample points reflected a spatial correlation that could be used to explain variations in the surface. The variation was to produce unbiased predictions with minimum variance and interpolation errors [12]. The kriging was used as an exploratory statistical analysis to understand the patterns of the water quality parameters. It was also used for variogram modeling and creating the surface output grids. The general formula for interpolators is formed as a weighted sum of the data.

The fundamental aspect was an estimation of the semivarogram to determine the spatial correlation or dependence from the observed data. This was estimated from half the expected squared difference between paired data values $z(x)$ and $z(x+h)$ to the distance lag $\mathrm{h}$, by which locations are separated. The statistical package $\mathrm{R}$ as in [13] [14] [15] was used to obtain this.

$$
Y(h)=1 / 2 E[Z(X)-Z(X+h)]^{2}
$$

where $Z\left(X_{i}\right)$ is the value of the variable $Z$ at location of $X_{p} h$ is the lag distance, $N$ is the number of measured values and $N(h)$ is the number of pairs of sample points separated by $h$.

$$
Y(h)=1 / 2 N(h) \sum_{i=1}^{N}\left[Z(X)-Z\left(X_{i}+h\right)\right]^{2}
$$

After estimating the semivariogram, the values were estimated through theoretical models (circular, spherical, Gaussian, linear, exponential) and these were provided in 3D Analyst in ArcGIS. The selected model influenced the prediction of the unknown values, particularly when the shape of the curve near the origin differs significantly. The characteristics of the model (range, sill and nugget) enabled the understanding of a semivariogram. The range refers to the distance where the model first flattens out. The nugget effect was attributed to measurement errors or spatial sources of variations at distances smaller than the sampling interval and the sill depicted the value at which the model attained the range-the value at the y axis called the sill.

Ordinary kriging was used because of its' simplicity and accuracy. For ordinary kriging, a probability model is used where the bias and the error variance can be calculated ensuring that the average error for the model is close to zero and also minimizes the error variance [16]. 


\section{Results}

\subsection{Physico-Chemical Parameters}

A generalized information of the analyzed samples with respect to minimum, maximum, mean and standard deviation of water quality variables are presented in Table 1 for the dry season and Table 2 for the wet season data. Apart from water temperature, $\mathrm{pH}$, electrical conductivity, dissolved oxygen, TDS, calcium, magnesium and chlorine; the other water variables (salinity, nitrates, phosphates, bicarbonate, sulphate, sodium and potassium) were within the desirable limit set aside by WHO. The obtained water quality parameters were compared with WHO drinking water standards [17].

The trend for average variation of water temperature and dissolved oxygen for Douala IV for the dry and wet seasons is graphically represented in Figure 1. According to the $\mathrm{WHO}$, the standards of safe drinking water; water temperature and DO should not exceed $15^{\circ} \mathrm{C}$ and be less than $5 \mathrm{mg} / \mathrm{L}$ respectively. Analyzed values of water samples for the study area ranged from 26 to 30.3 and 25.55 to 26.93 for the dry sea and wet season respectively. This indicates very high values of water temperature. The extreme values could be probably as a result of differences in season.

The DO of all samples ranged from 0.95 to $3.9 \mathrm{mg} / \mathrm{L}$ (dry) and 1.18 to 3.7 $\mathrm{mg} / \mathrm{L}$ (wet) season indicating that it falls below the limit set aside by WHO

Table 1. Statistical summary of physico-chemical data of dry season ground water and surface water for Douala IV.

\begin{tabular}{|c|c|c|c|c|c|c|c|c|c|c|c|c|c|c|c|c|c|c|c|c|}
\hline \multirow{2}{*}{ Parameters } & \multicolumn{4}{|c|}{ Costal transect $(n=4)$} & \multicolumn{4}{|c|}{ Inner transect $1(n=4)$} & \multicolumn{4}{|c|}{ Inner transect $2(n=4)$} & \multicolumn{4}{|c|}{ Inner transect $3(n=4)$} & \multicolumn{4}{|c|}{ Surface water $(n=4)$} \\
\hline & Min & $\operatorname{Max}$ & Mean & Std D & Min & $\operatorname{Max}$ & Mean & Std D & Min & $\operatorname{Max}$ & Mean & Std D & Min & Max & Mean & Std D & Min & Max & Mean & Std D \\
\hline $\begin{array}{l}\text { Water } \\
\text { Temp. }\end{array}$ & 26 & 29 & 27.7 & 0.81 & 27 & 30.2 & 28.14 & 0.85 & 27 & 28.9 & 27.9 & 0.69 & 26.8 & 29 & 28.02 & 0.69 & 29.9 & 30.3 & 30.1 & 0.21 \\
\hline $\mathrm{pH}$ & 5.16 & 6.52 & & 0.39 & 4 & 6.19 & & 0.725 & 5.13 & 6.95 & & 0.59 & 3.89 & 6.21 & & 0.77 & 6.49 & 6.89 & & 0.20 \\
\hline EC & 61 & 7540 & 1661.5 & 2235.53 & 44.6 & 594 & 336.72 & 221.1 & 45 & 1952 & 629 & 662 & 76 & 226 & 136.39 & 61.08 & 1660 & 10,500 & 7388 & 4977.8 \\
\hline Salinity & 0 & 4.2 & 0.825 & 1.28 & 0 & 0.2 & 0.11 & 0.09 & 0 & 1 & 0.3 & 0.4 & 0 & 0.1 & 0.01 & 0.03 & 0.8 & 6 & 4.16 & 2.90 \\
\hline DO & 0.25 & 2.71 & 0.955 & 0.94 & 0.99 & 2.47 & 1.80 & 0.481 & 0.18 & 1.87 & 1.08 & 0.65 & 0.67 & 5.17 & 2.68 & 1.20 & 3.02 & 5.63 & 3.97 & 1.44 \\
\hline TDS & 31 & 3750 & 837.75 & 1112.76 & 25 & 300 & 170.25 & 113.2 & 20 & 965 & 344 & 351 & 32 & 130 & 70.33 & 33.21 & 810 & 5300 & 3703.33 & 32510. \\
\hline $\mathrm{NO}_{3}^{-}$ & 0 & 20.14 & 4.495 & 6.86 & 1 & 57.4 & 16.46 & 17.9 & 0.4 & 17.2 & 5.48 & 5.23 & 1.2 & 34 & 10.91 & 9.50 & 0.16 & 3.33 & 1.98 & 1.63 \\
\hline $\mathrm{PO}_{4}^{3-}$ & 0.04 & 5.2 & 1.035 & 1.41 & 0.03 & 6.1 & 0.83 & 1.704 & 0.02 & 1.2 & 0.52 & 0.44 & 0.12 & 1.4 & 0.42 & 0.36 & 0.11 & 0.16 & 0.14 & 0.03 \\
\hline $\mathrm{HCO}_{3}^{-}$ & 0.2 & 5.5 & 1.3125 & 1.49 & 0.1 & 5 & 1.77 & 1.459 & 0.1 & 6.5 & 2.3 & 2.31 & 0.1 & 15 & 2.70 & 4.05 & 0.11 & 1.00 & 0.65 & 0.50 \\
\hline $\mathrm{SO}_{4}^{2-}$ & 8 & 97 & 44.75 & 29.17 & 0 & 43 & 11.17 & 14.58 & 0 & 103 & 47 & 47.5 & 0 & 27 & 10.50 & 11.01 & 59 & 220 & 158 & 86.6 \\
\hline $\mathrm{Ca}^{2+}$ & 20 & 80 & 42.73 & 18.26 & 4 & 84 & 30.67 & 22.26 & 12 & 256 & 85 & 85.4 & 8 & 44 & 20.33 & 10.98 & 12 & 72 & 36 & 31.7 \\
\hline $\mathrm{Mg}^{2+}$ & 2.4 & 69.6 & 21.8 & 21.82 & 0 & 19.2 & 8.20 & 6.428 & 0 & 98.4 & 20.4 & 27.6 & 0 & 31.2 & 6.60 & 9.27 & 12 & 110.4 & 49.6 & 53.1 \\
\hline $\mathrm{Na}^{+}$ & 3 & 73 & 30.92 & 23.11 & 8 & 53 & 20.08 & 11.77 & 3 & 63 & 29.4 & 19.2 & 3 & 123 & 34.58 & 34.05 & 13 & 23 & 16.33 & 5.77 \\
\hline $\mathrm{K}^{+}$ & 0 & 1.47 & 0.45 & 0.58 & 0 & 10.8 & 1.56 & 3.358 & 0 & 9.6 & 1.35 & 3.14 & 0 & 5.47 & 0.64 & 1.55 & 0 & 0.13 & 0.04 & 0.075 \\
\hline $\mathrm{Cl}^{-}$ & 1 & 223.6 & 88.58 & 76.40 & 0 & 95.2 & 19.24 & 27.73 & 0.3 & 61.3 & 17.8 & 18.2 & 0.8 & 34.6 & 7.53 & 9.85 & 9.7 & 243 & 122.9 & 116.81 \\
\hline
\end{tabular}


Table 2. Statistical summary of physico-chemical data of wet season ground water and surface water for Douala IV.

\begin{tabular}{|c|c|c|c|c|c|c|c|c|c|c|c|c|c|c|c|c|c|c|c|c|}
\hline \multirow{2}{*}{ Parameters } & \multicolumn{4}{|c|}{ Coastal transect $(\mathrm{n}=4)$} & \multicolumn{4}{|c|}{ Inner transect $(n=4)$} & \multicolumn{4}{|c|}{ Inner transect $2(n=4)$} & \multicolumn{4}{|c|}{ Inner transect $3(n=4)$} & \multicolumn{4}{|c|}{ Surface water $(n=3)$} \\
\hline & Min & $\operatorname{Max}$ & Mean & Std D & Min & $\operatorname{Max}$ & Mean & Std D & Min & $\operatorname{Max}$ & Mean & Std D & Min & $\operatorname{Max}$ & Mean & Std D & $\min$ & $\max$ & mean & Std D \\
\hline $\begin{array}{l}\text { Water } \\
\text { Temp. }\end{array}$ & 25.7 & 28 & 26.67 & 0.77 & 26.6 & 27.4 & 26.93 & 0.23 & 25 & 28 & 26.69 & 0.77 & 26 & 27.3 & 26.82 & 0.45 & 25 & 26.3 & 25.55 & 0.46 \\
\hline $\mathrm{pH}$ & 5.39 & 7.24 & & 0.61 & 4.44 & 6.99 & & 0.83 & 5.06 & 6.96 & & 0.57 & 5.05 & 6.7 & & 0.55 & 5.87 & 6.91 & & 0.46 \\
\hline $\mathrm{EC}$ & 170 & 2947 & 660.63 & 767.7 & 0 & 697 & 324.20 & 205.29 & 0 & 1637 & 571.00 & 513.76 & 0 & 790 & 208.91 & 233.67 & 49.1 & 415 & 226.60 & 151.95 \\
\hline Salinity & 0 & 1.6 & 0.30 & 0.43 & 0 & 0.3 & 0.14 & 0.09 & 0 & 0.8 & 0.25 & 0.27 & 0 & 0.28 & 0.05 & 0.08 & 0 & 0.1 & 0.07 & 0.05 \\
\hline DO & 0.29 & 4.4 & 1.22 & 1.17 & 0.27 & 3.25 & 1.78 & 0.96 & 0.26 & 3.95 & 1.18 & 0.99 & 0 & 6.86 & 2.60 & 2.10 & 3.07 & 4.49 & 3.70 & 0.57 \\
\hline TDS & 58.4 & 1467 & 317.06 & 388.07 & 16.19 & 349 & 153.73 & 98.57 & 28.1 & 819 & 273.33 & 259.42 & 15.79 & 284 & 76.86 & 75.16 & 23 & 209 & 111.82 & 77.10 \\
\hline $\mathrm{NO}_{3}^{-}$ & 0 & 21.3 & 7.33 & 6.01 & 0 & 23.6 & 6.69 & 8.73 & 0 & 13 & 4.65 & 4.04 & 0.5 & 11 & 4.41 & 2.86 & 0.7 & 25.3 & 7.02 & 9.17 \\
\hline $\mathrm{PO}_{4}^{3-}$ & 0.09 & 1.49 & 0.44 & 0.38 & 0.06 & 0.68 & 0.28 & 0.17 & 0.11 & 0.69 & 0.30 & 0.17 & 0.06 & 2.41 & 0.44 & 0.65 & 0.12 & 1.54 & 0.46 & 0.55 \\
\hline $\mathrm{HCO}_{3}^{-}$ & 0.1 & 3.5 & 0.64 & 0.94 & 0.05 & 1.5 & 0.47 & 0.55 & 0.15 & 2 & 0.67 & 0.63 & 0.05 & 3.5 & 0.78 & 1.15 & 0.1 & 0.2 & 0.15 & 0.03 \\
\hline $\mathrm{SO}_{4}^{2-}$ & 0 & 57 & 13.92 & 18.39 & 3 & 34 & 11.50 & 9.65 & 2 & 99 & 40.08 & 38.89 & 0 & 72 & 17.08 & 20.96 & 1 & 15 & 8.83 & 6.27 \\
\hline $\mathrm{Ca}^{2+}$ & 0.06 & 65 & 11.44 & 19.92 & 0.09 & 56 & 10.96 & 19.79 & 0.06 & 85 & 14.07 & 26.91 & 0.09 & 65 & 11.91 & 20.65 & 0.09 & 0.49 & 0.25 & 0.18 \\
\hline $\mathrm{Mg}^{2+}$ & 0.05 & 28 & 6.49 & 10.97 & 0.05 & 40 & 7.46 & 12.81 & 0.05 & 28 & 7.46 & 10.94 & 0.1 & 34 & 7.67 & 12.81 & 0.25 & 5 & 1.22 & 1.86 \\
\hline $\mathrm{Na}^{+}$ & 0 & 89 & 25.33 & 24.76 & 0 & 43 & 16.33 & 12.81 & 3 & 53 & 17.92 & 17.37 & 0 & 61 & 20.67 & 18.85 & 3 & 43 & 16.33 & 15.06 \\
\hline $\mathrm{K}^{+}$ & 0 & 1.2 & 0.18 & 0.39 & 0 & 1.47 & 0.24 & 0.52 & 0 & 1.47 & 0.31 & 0.47 & 0 & 2.3 & 0.39 & 0.79 & 0 & 1.47 & 0.38 & 0.62 \\
\hline $\mathrm{Cl}^{-}$ & 0 & 234.5 & 60.12 & 90.18 & 0 & 125.7 & 31.76 & 42.60 & 0 & 135.9 & 31.25 & 46.74 & 0 & 30.4 & 5.88 & 9.29 & 6.1 & 114 & 40.07 & 37.57 \\
\hline
\end{tabular}

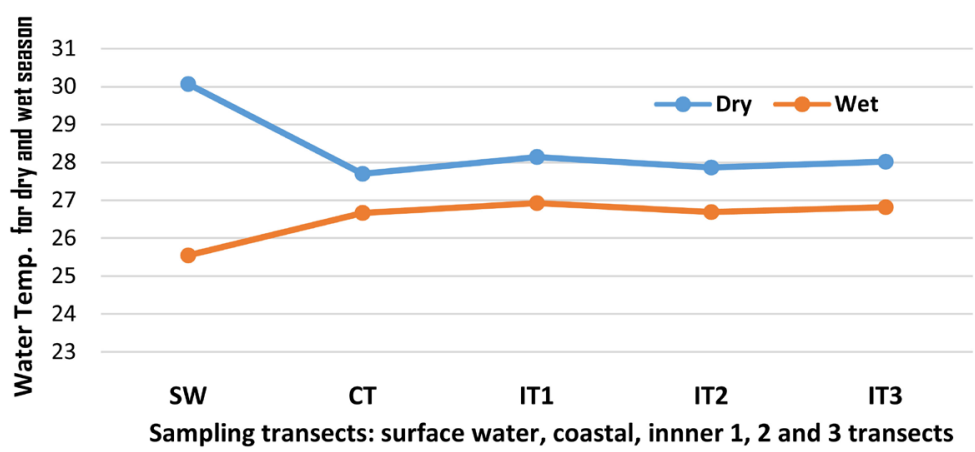

(a)

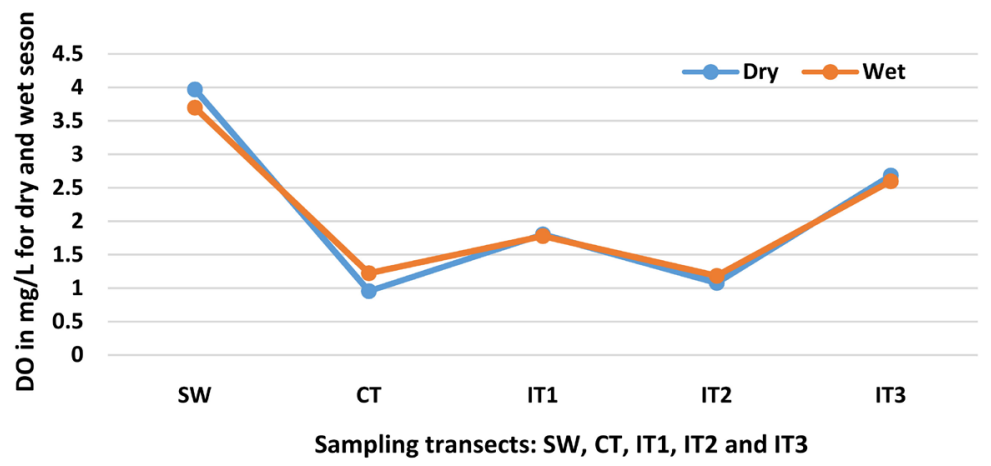

(b)

Figure 1. Dry and wet season trend over sampling transects of fresh water resources in Douala IV. (a) Water temperature; (b) Dissolved oxygen. 
(should not be less than $5 \mathrm{mg} / \mathrm{L}$ ). Higher water temperatures could be responsible for the decrease in DO because the solubility of DO decreases with an increase in temperature [18]. The high water temperatures $\left(25^{\circ} \mathrm{C}-30^{\circ} \mathrm{C}\right)$ and low DO $(0.95-3.9 \mathrm{mg} / \mathrm{L})$ can influence chemical and biological processes in water bodies which might increase the concentrations of harmful cations and/or anions in water resources.

The variation in $\mathrm{pH}$ data for the different transect sampling stations is shown in Figure 2. The range of desirable limit for $\mathrm{pH}$ of water prescribed for drinking purpose by WHO is 6.5 to 8.5. The $\mathrm{pH}$ of analysed water samples varied from 3.89 to 6.89 for the dry season and 4.4 to 6.99 for the wet season indicating a tendency towards acidic water for some of the water samples. It is important to control $\mathrm{pH}$ in water so as to minimize corrosion or incrustation [19]. Such $\mathrm{pH}$ values can cause damage to the water supply systems with other interacting parameters like temperature.

The average variation in EC and TDS for the sampling stations is shown in Figure 3. The range of desirable limit for EC and TDS prescribed for drinking purpose by WHO are $750 \mu \mathrm{S} / \mathrm{cm}$ and $1000 \mathrm{mg} / \mathrm{L}$ respectively. EC and TDS are interrelated because EC estimates the amount of total dissolved salts.

EC ranged from 208.91 to 660.63 and 45 to $7540 \mu \mathrm{S} / \mathrm{cm}$ for the wet and dry seasons, respectively. The TDS ranged from 15.79 to 1467,20 to $3750 \mathrm{mg} / \mathrm{L}$ for the wet and dry seasons, respectively. The coastal transect (1a) had the highest TDS value and the value for the dry season was elevated probably due to the evaporation of water due to high temperatures and the lack of replenishment due to no rainfall episodes. TDS increases could lead to gastro intestinal irritation [20] and [21] and so needs special attention. High levels of TDS could similarly be caused by the presence of potassium, chlorides and sodium. Reference [22] illustrates that high TDS indicates hard water which can result in undesirable taste (salty, bitter or metallic). He indicated that high TDS was associated with undesirable taste for mangroves from the Lagos lagoon in Nigeria.

The average variation for calcium and magnesium hardness values for the different transect stations is shown in Figure 4.

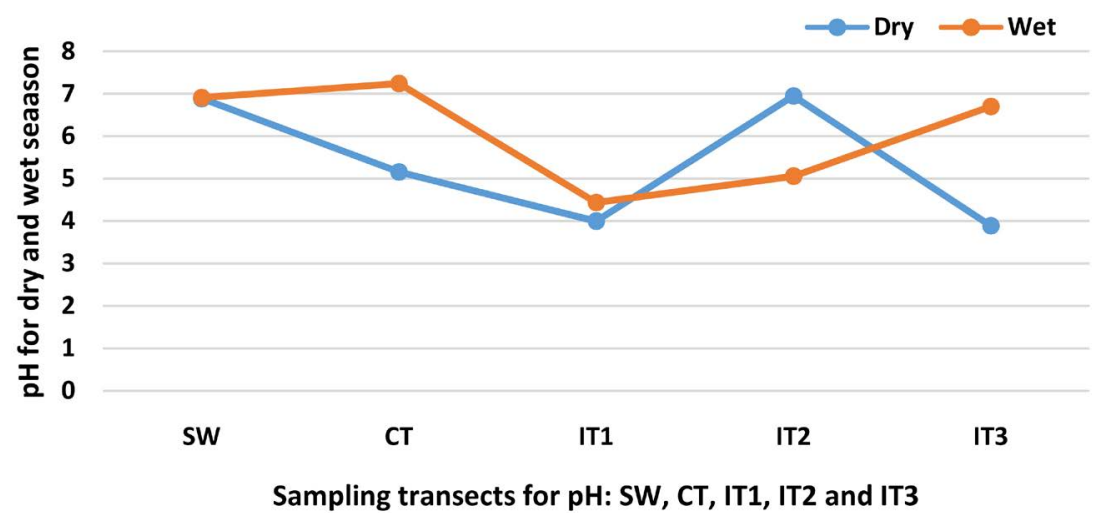

Figure 2. $\mathrm{pH}$ trend against sampling transects for dry and wet season freshwater resources in Douala. 


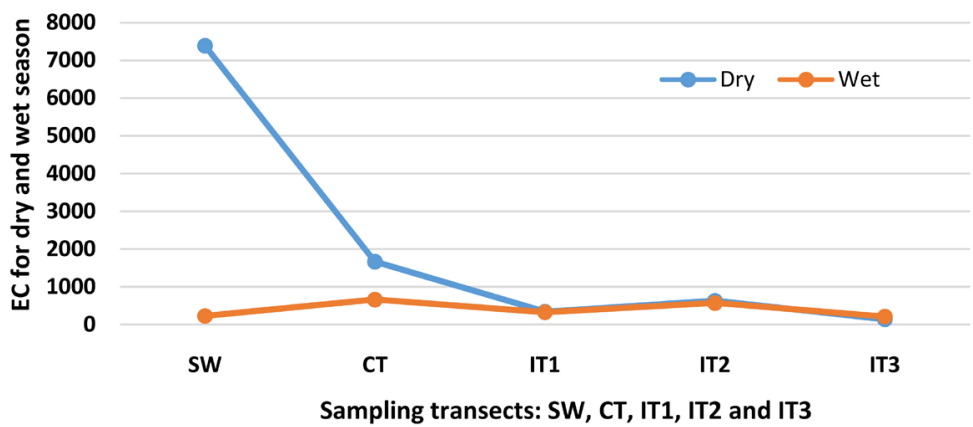

(a)

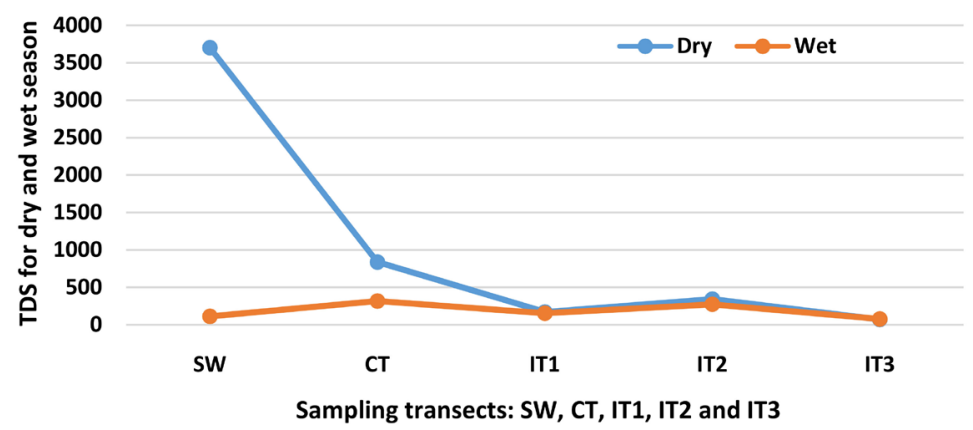

(b)

Figure 3. Dry and wet season EC and TDS trend against sampling transects of fresh water resources for Douala IV. (a) Electrical conductivity; (b) Total dissolved solids.

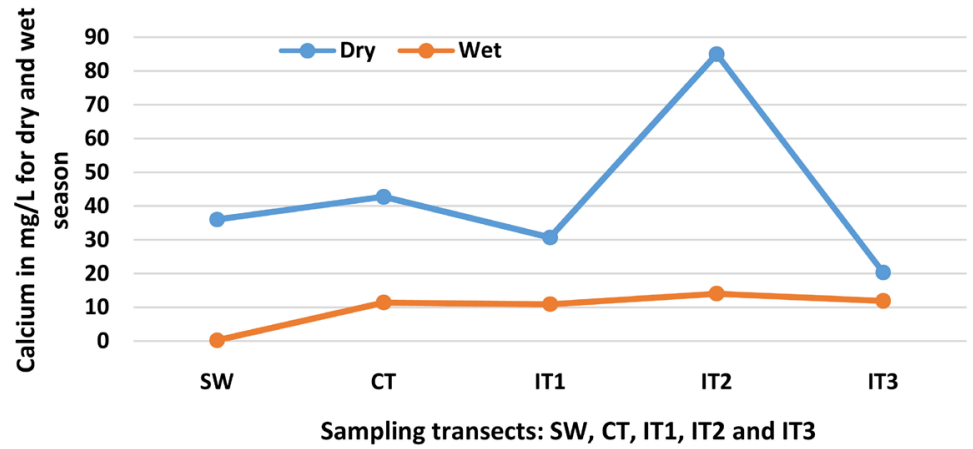

(a)

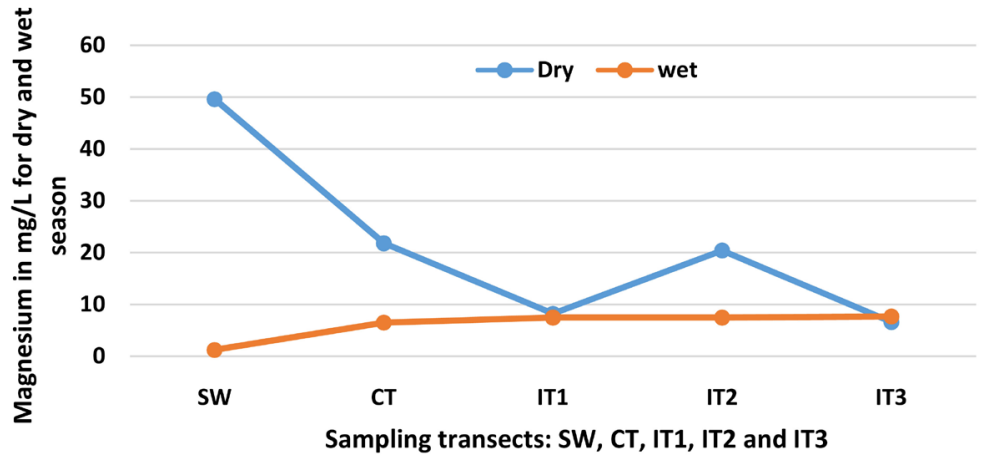

(b)

Figure 4. Dry and wet season calcium and magnesium trends against sampling transects of fresh water resources for Douala IV. (a) Calcium; (b) Magnesium. 
The range of desirable limit for calcium and magnesium hardness of water prescribed for drinking proposed by WHO are $75 \mathrm{mg} / \mathrm{L}$ and $30 \mathrm{mg} / \mathrm{L}$ respectively. From the study, calcium hardness was in the range of 0.06 to $85 \mathrm{mg} / \mathrm{L}$ and 4 to $256 \mathrm{mg} / \mathrm{L}$ for wet and dry seasons respectively while magnesium was in the range of 0.05 to $40 \mathrm{mg} / \mathrm{L}$ and 2.4 to $98.4 \mathrm{mg} / \mathrm{L}$ for wet and dry seasons respectively. One sample from inner transects two fell short of the desirable calcium limit for the dry season. One inner transect 1 and one inner transect 3 samples fell short of magnesium limit by WHO for the wet season. One sample each except the inner transects 1 sample for dry season fell short of the desirable magnesium limit set aside by WHO.

Higher values of calcium and magnesium during the dry season could be attributed to low water levels and high rate of evaporation of water and the addition of calcium and magnesium salts. Hardness does not pose a health risk but its presence can help ensure we get the average daily requirements for these minerals in the diet. However, hard water can be a nuisance due to mineral build up on plumbing fixtures and poor soap and detergent performance as reported by respondents from the field survey. It can cause aesthetic problems such as the appearance of fresh water resources, alkali taste to water, a build-up of scales on pipes and fixtures that can eventually lower water pressure. It is also associated with build-up deposits on dishes, utensils and laundry basins and difficulty in getting soap and detergent to foam and lowered efficiency of electric water heaters [23] and [24].

Sodium and potassium for the wet and dry seasons met the standard stipulated by WHO safe drinking water standard which stands at 200 and $100 \mathrm{mg} / \mathrm{L}$. Variations of chloride are shown in Figure 5.

The standard for chloride of drinking water purposes as prescribed by WHO is $200 \mathrm{mg} / \mathrm{L}$. One sample from the coastal transect fell below this value for both wet and dry seasons with values of 234.5 and 223.6 respectively (Table 1 and Table 2). Paradoxically, chloride value of 234.5 was observed to be the highest for the wet season. The closeness of this point to the ocean could account for this high value. This is likely indicative of salt water intrusion into ground water at these places. Generally, the continuous extraction of ground water along coastal regions often leads to the movement of saline sea water into fresh water wells, thereby degrading water quality [25] [26] [27].

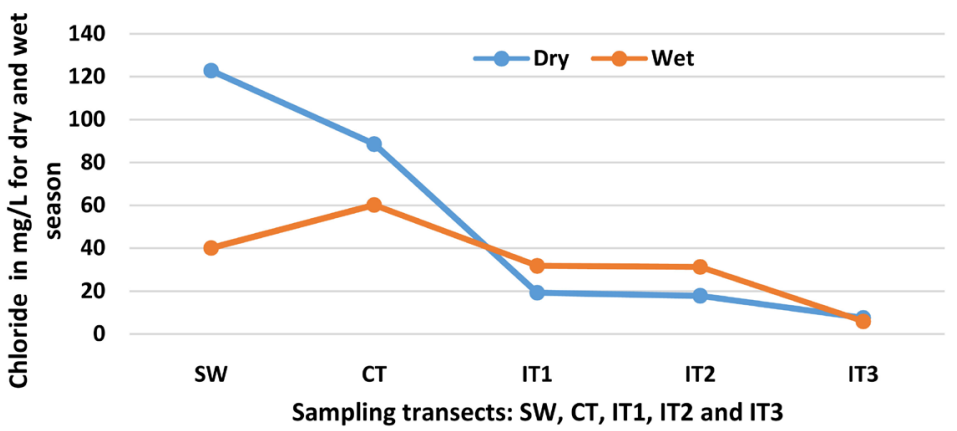

Figure 5. Dry and wet season fresh water quality of Chlorine for Douala IV. 


\subsection{Geostatistical Results}

The characteristic parameters (range, sill, range and best fitted models) of semivariogram models are shown in Table 3. The best fitted models for water quality parameters (Figure 6 and Figure 7) are indicated for dry and wet season respectively. Each of the figures represents the lag distance versus semi-variance values contributing a model with its different quantitative components. The line indicates the theoretical model that has been selected for prediction as most of the semi-variance values were close to that line as shown for some quality parameters.

Data from Douala IV wells which were subjected to spatial and temporal analysis indicated that SWI occurred for the wells. This has been similarly indicated by [28] for the neighboring district of Douala III and IV. Consequently, the integration of physicochemical data, spatial temporal relations and map modelling allowed for comprehensive identification of the sea water contaminated regions. Spatial distribution maps of well water quality parameters are shown in Figures 8-12.

Table 3. Characteristics parameters of selected semi-variogram models.

\begin{tabular}{|c|c|c|c|c|}
\hline Water parameters & Best fitted model & Range & Sill & Nugget \\
\hline Water temperature & spherical & 2000 & 0.0011 & 0.0001 \\
\hline $\mathrm{pH}$ & spherical & 2000 & 0.03 & 0.001 \\
\hline EC & Gaussian & 1500 & 1.5 & 0.2 \\
\hline Dissolved oxygen & spherical & 1900 & 0.65 & 0.05 \\
\hline TDS & spherical & 2500 & 3 & 0.2 \\
\hline Phosphates & Exponential & 1600 & 0.5 & 0.2 \\
\hline Bicarbonate & Exponential & 2000 & 1 & 0.125 \\
\hline Calcium & Gaussian & 1750 & 0.52 & 0.10 \\
\hline Sodium & Gaussian & 1750 & 0.17 & 0.05 \\
\hline Chlorine & Gaussian & 1000 & 0.9 & 0.45 \\
\hline $\mathrm{pH}(\mathrm{w})$ & Spherical & 1250 & 0.002 & 0.0005 \\
\hline EC (wet) & Gaussian & 1500 & 0.27 & 0.015 \\
\hline Water temperature (w) & Gaussian & 2000 & 0.0011 & 0.0001 \\
\hline Salinity (w) & Spherical & 800 & 0.011 & 0.001 \\
\hline Dissolved oxygen (w) & Spherical & 1500 & 0.35 & 0.05 \\
\hline TDS (w) & Spherical & 1100 & 0.27 & 0.01 \\
\hline Nitrates (w) & Gaussian & 800 & 0.023 & 0.01 \\
\hline Phosphates (w) & Spherical & 1500 & 0.09 & 0.000 \\
\hline Bicarbonate (w) & Gaussian & 900 & 0.22 & 0.05 \\
\hline Sulphate (w) & Gaussian & 600 & 0.53 & 0.2 \\
\hline Calcium (w) & Spherical & 1250 & 0.40 & 0.11 \\
\hline Sodium (w) & Gaussian & 1000 & 0.15 & 0.03 \\
\hline Chlorine (w) & Spherical & 1200 & 1 & 0.6 \\
\hline
\end{tabular}

$\mathrm{W}=$ wet season values. 

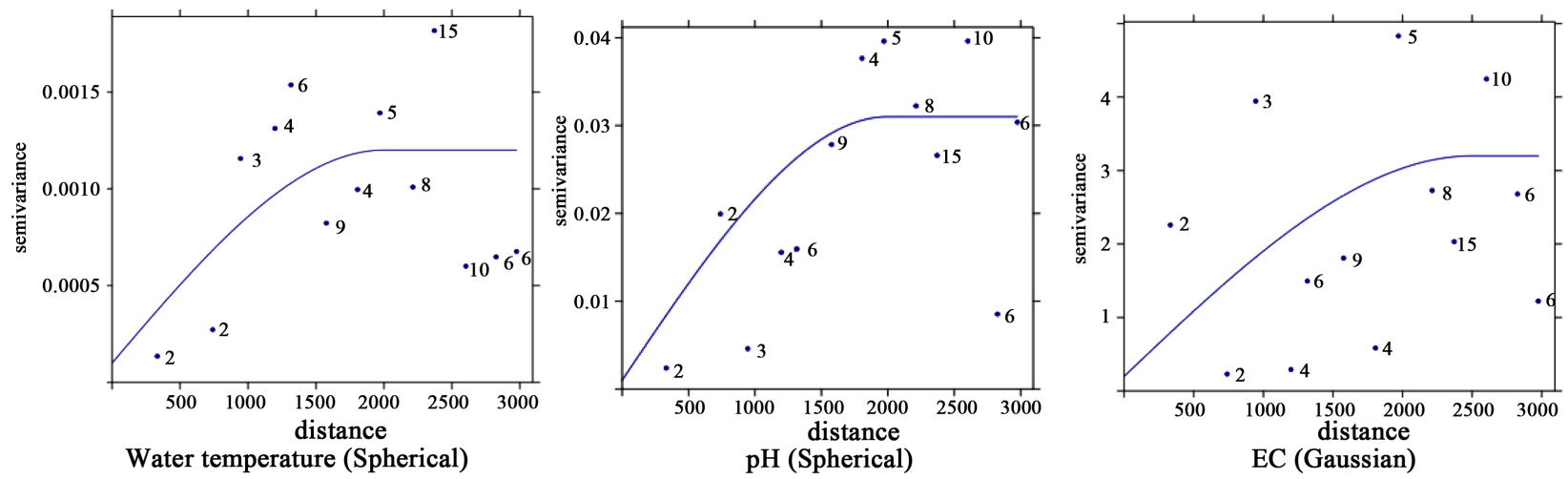

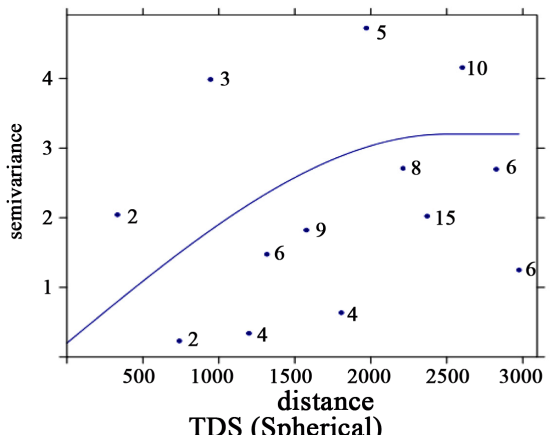

TDS (Spherical)

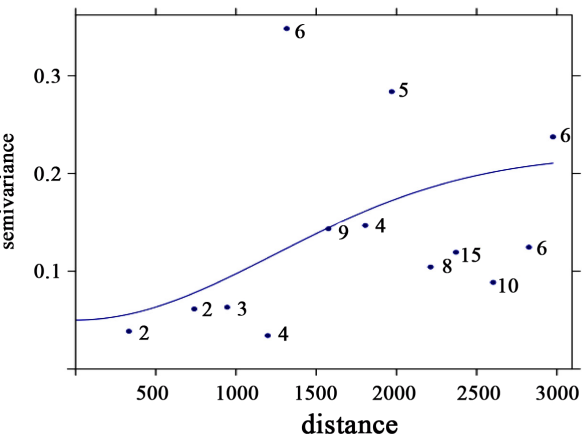

Sodium (Gaussian)

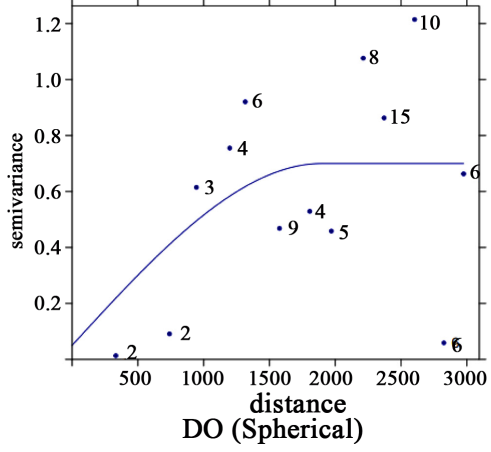

(a)

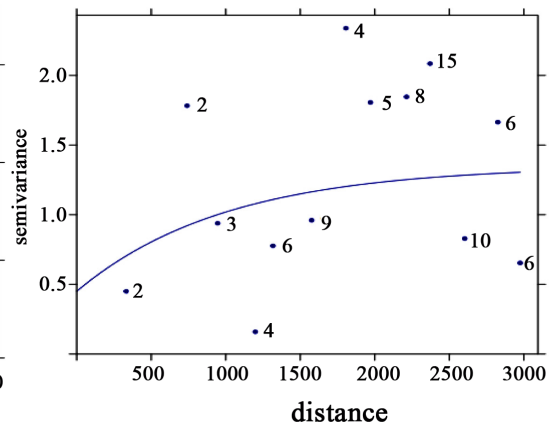

Chlorine (Gaussian)

(b)

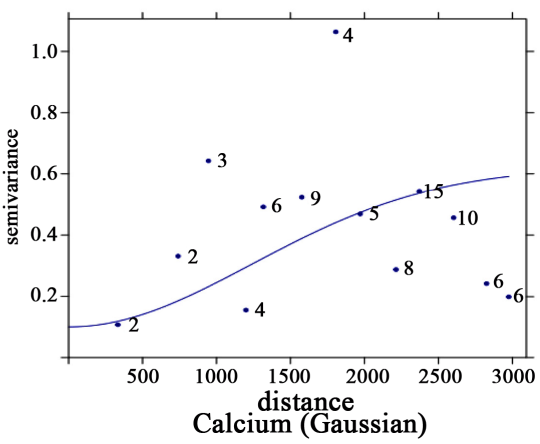

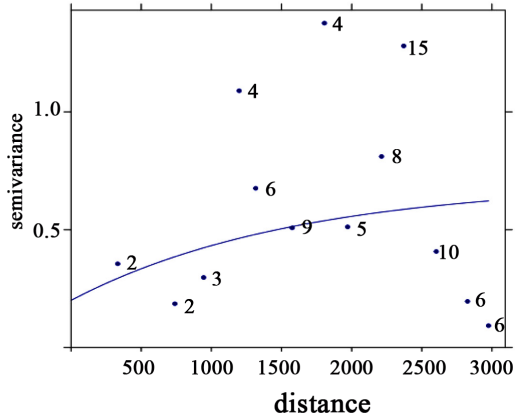

Phospahte (Exponential)

Figure 6. Best fitted semi-variogram models for dry season water quality parameters.

From the variograms, it is clear that there is a spatial dependence of sampled points for the dry and wet season water. The dry and wet water season ranges for the different variables obtained from the best fit method indicated that spatial dependence ceases beyond those points. This implies that there are no more correlations from those points.

Figure 8 showed that the grids for both wet and dry season temperature were spatially distributed. Maximum highs of $27^{\circ} \mathrm{C}$ for the wet season were observed in the South Eastern region of the study area (Marin Haut, Entrée Marin Haut and Mbanjo) and at the North Western part of Bonjongo Central and Entrée Siac. Temperature highs for the dry season were observed at the South Eastern part of the study area (Marin Haut, Bonamikanou) and the North Western 


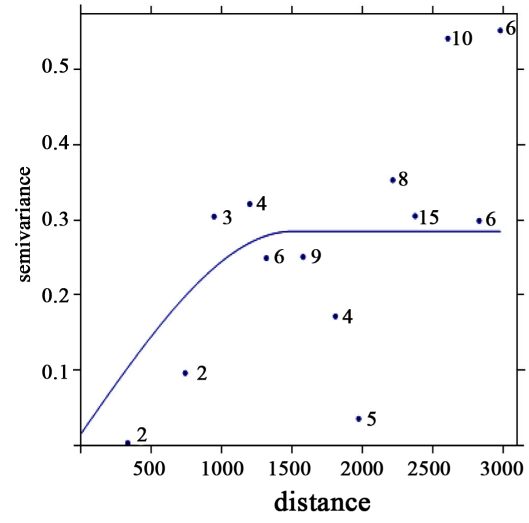

EC (Gaussian)

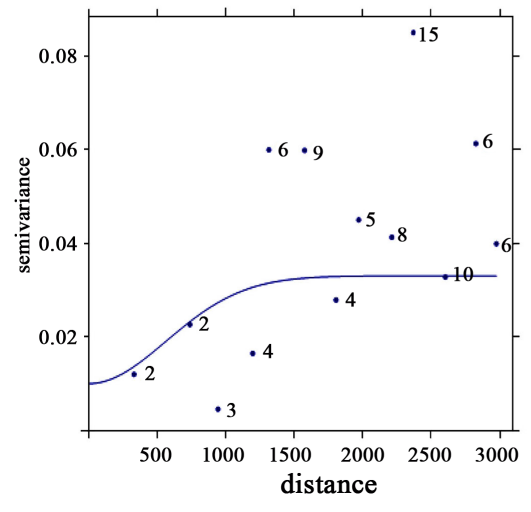

Nitrates (Gaussian)
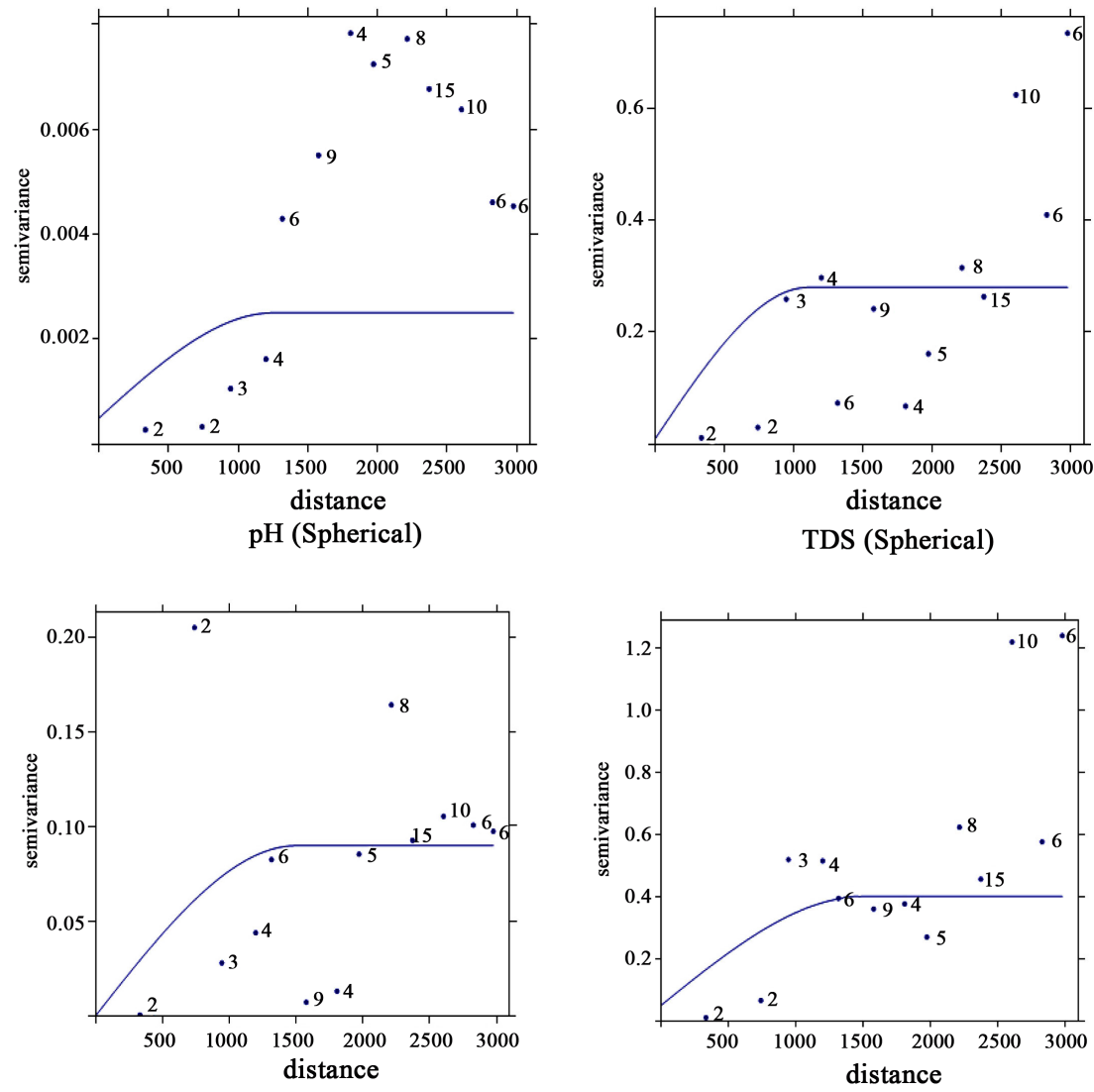

Phosphates (Spherical)

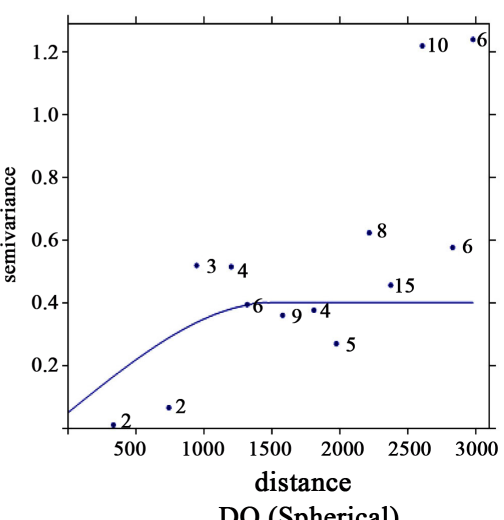

DO (Spherical)

Figure 7. Empirical variogram with fitted model superimposed for wet season variables for Douala IV.

region of Entrée Siac, Bojongo Central and Slaughter House Ndobo with maximum highs of $28^{\circ} \mathrm{C}$.

Very low values of DO $(0.235 \mathrm{mg} / \mathrm{L})$ for the dry season output were observed at the Northern area of the study area (Slaughter House Ndobo) and at the South Eastern area (EU funded well at the coastal region of Mabanda and behind Lycee de Mabanda) while wet season lows of $0.78 \mathrm{mg} / \mathrm{L}$ of DO were observed at the Northern area (Bonendale, Slaughter House Ndobo and Entrée Ngwele) in the study region.

A similar trend for the maximum highs of dry and wet seasons TDS (1800, $400 \mathrm{mg} / \mathrm{L})$, EC (1790 and $820 \mu \mathrm{S} / \mathrm{cm})$ and salinity $(0.842$ and $0.38 \mathrm{mg} / \mathrm{L})$ was observed (Figure 10). These were all located in the South Eastern region of the study area (EU funded well Mabanda and behind Lycee de Mabanda) for the two wells.

The trend for wet and dry season output grid for sodium showed variation in its distribution (Figure 11). Maximum highs $(58 \mathrm{mg} / \mathrm{L}$ ) of dry season values are observed in the North Western region of Bojongo while that for the wet season highs $(24 \mathrm{mg} / \mathrm{L})$ were found in the South Eastern part. This same pattern of spatial distribution was observed for chlorine highs $110 \mathrm{mg} / \mathrm{L}$ (dry) and $104 \mathrm{mg} / \mathrm{L}$ (wet) for the analysis. 

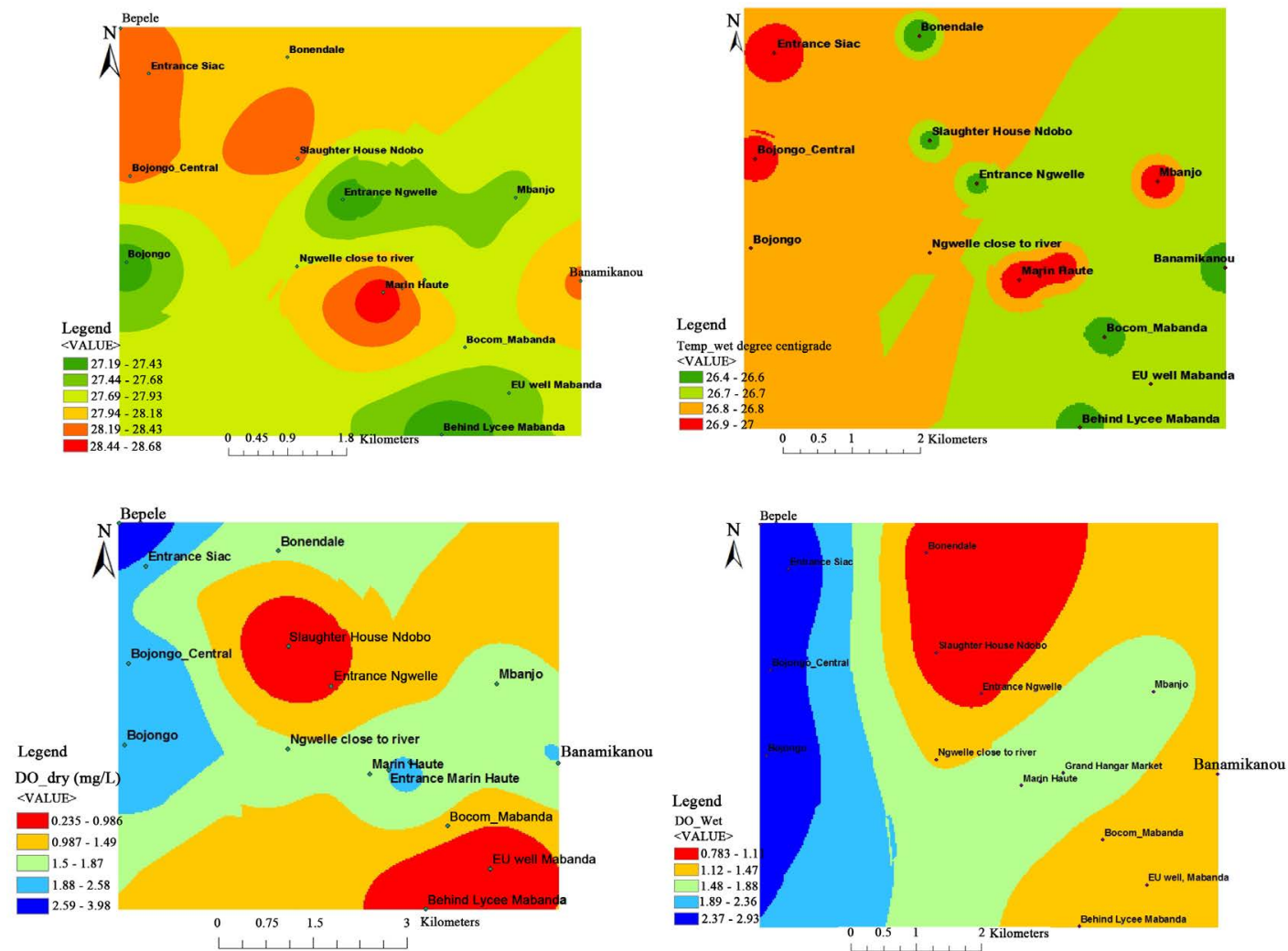

Figure 8. Output grids of spatial distribution pattern of wet and dry season parameters (Water temperature and DO for Douala IV).
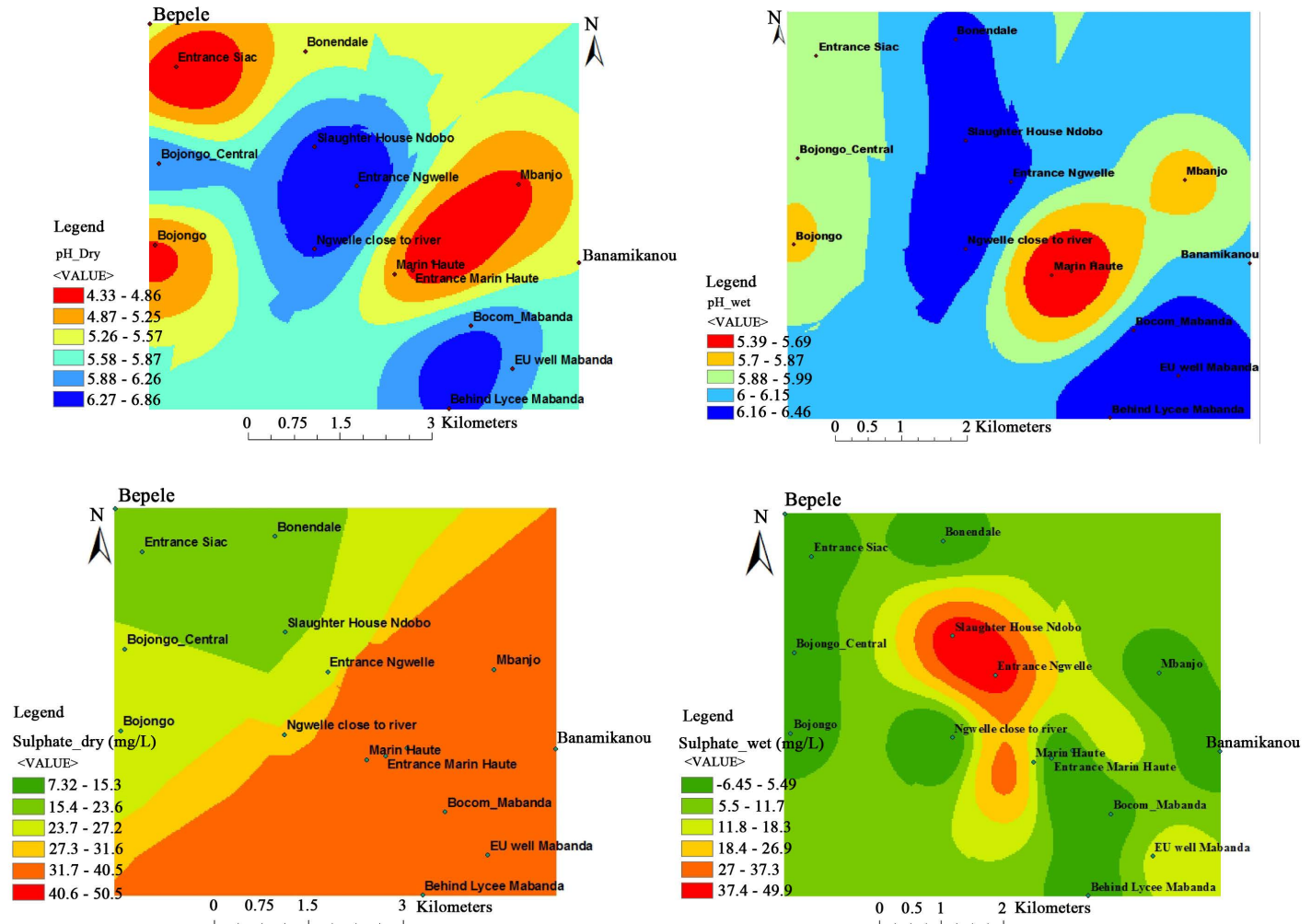

Figure 9. Output grids of spatial distribution pattern of wet and dry season parameters (pH and Sulphate) for Douala IV. 

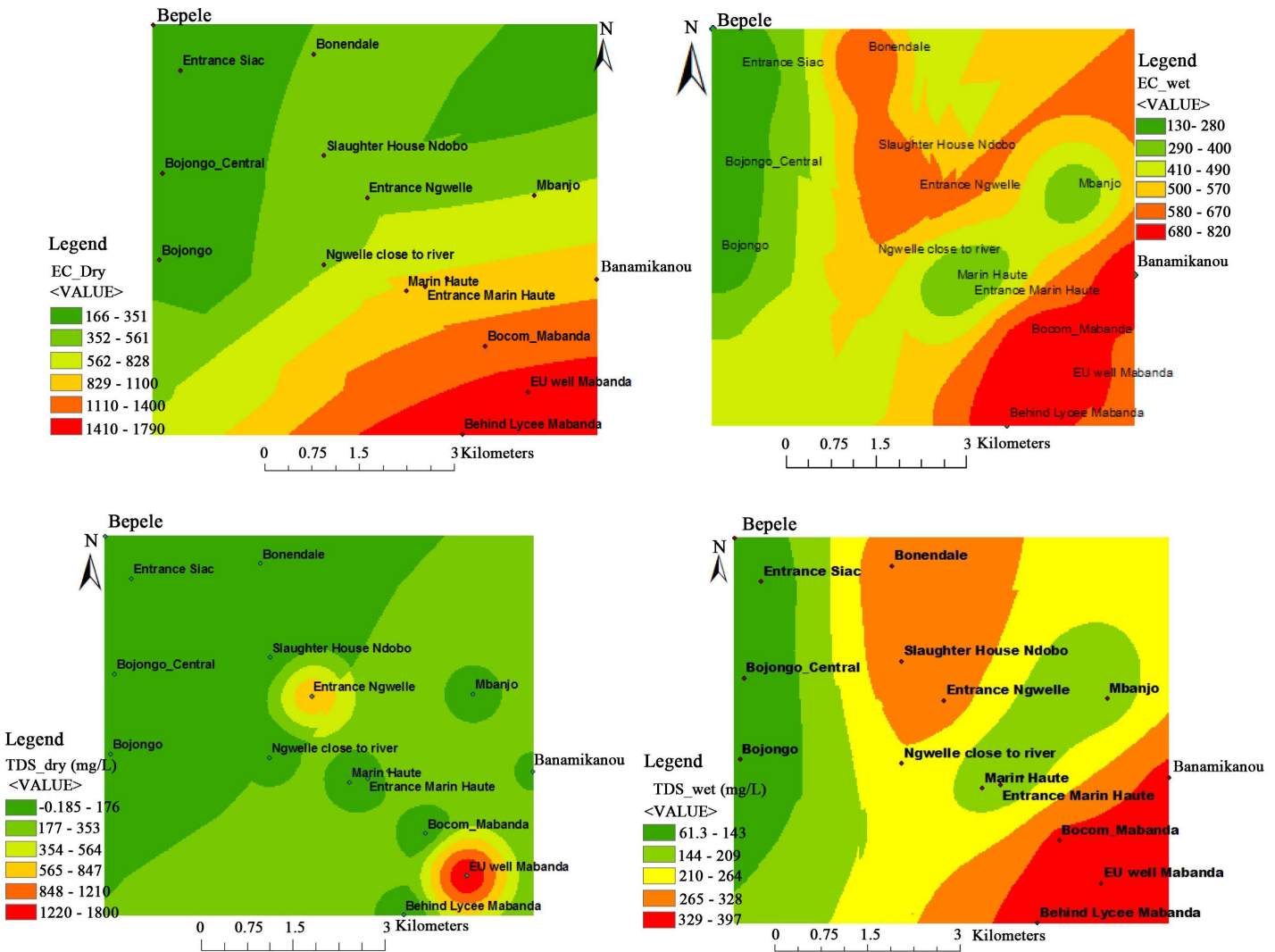

Figure 10. Output grids of spatial distribution pattern of wet and dry season parameters (EC and TDS) for Douala IV.
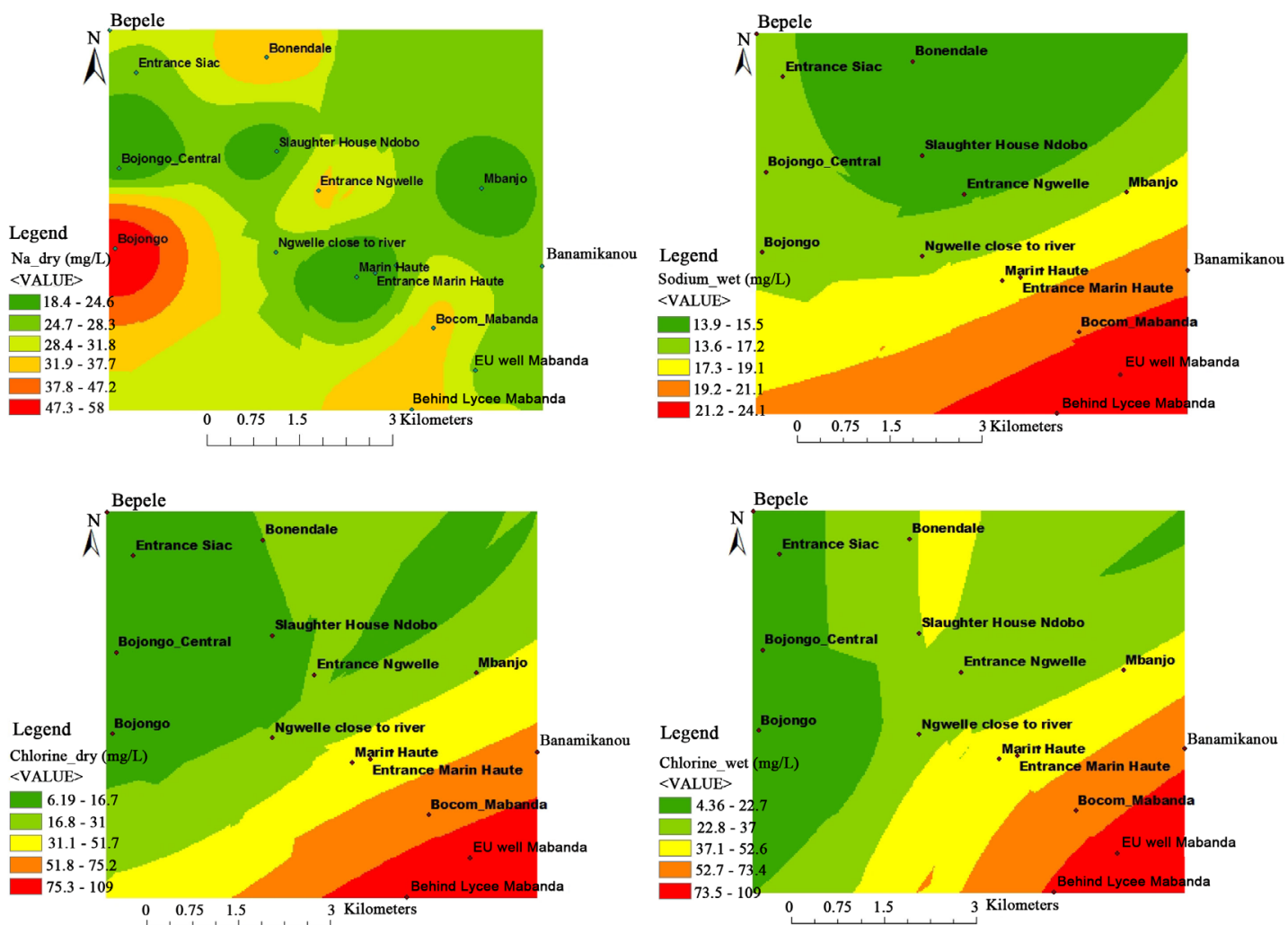

Figure 11. Output grids of spatial distribution pattern of wet and dry season parameters (sodium and chlorine) for Douala IV. 
The output grids generated for calcium and magnesium (Figure 12) are diverse both spatially and temporally. Maximum highs (140 and $16 \mathrm{mg} / \mathrm{L}$ ) for dry and wet season calcium are observed. Highs for dry season calcium are centrally located (Entrée Ngwelle and Close to Ngwelle stream) while those for wet season are observed from South Eastern area of the study region spreading north ward. Magnesium highs (37.5 and $10 \mathrm{mg} / \mathrm{L}$ ) for dry and wet season grids are shown. While magnesium highs are concentrated in the Northern and South Eastern region for the dry season analysis, the wet season data are found in the South Western region of the study.

Nitrate highs for dry $(4.57 \mathrm{mg} / \mathrm{L})$ and wet $(9 \mathrm{mg} / \mathrm{L})$ seasons were observed. Dry season highs are observed in the Northern region of the study area while wet season highs are found in the South Eastern part of the study area.

\section{Discussion}

The average temperature values of the study area were high with maximum values of $26.7^{\circ} \mathrm{C}$ for wet and $28^{\circ} \mathrm{C}$ for dry seasons. These values are higher than the $15^{\circ} \mathrm{C}$ standards stipulated by [17]. Elevated temperature values influence many biological and chemical processes [18]. This probably explains why DO values of the study area are so low and do not meet with the $5 \mathrm{mg} / \mathrm{L}$ stipulated by WHO. An increase in temperature decreases the solubility of DO in water. Reference [29] shows that low oxygen values can be attributed to saline waters and vice versa since salinity influences the solubility of DO.
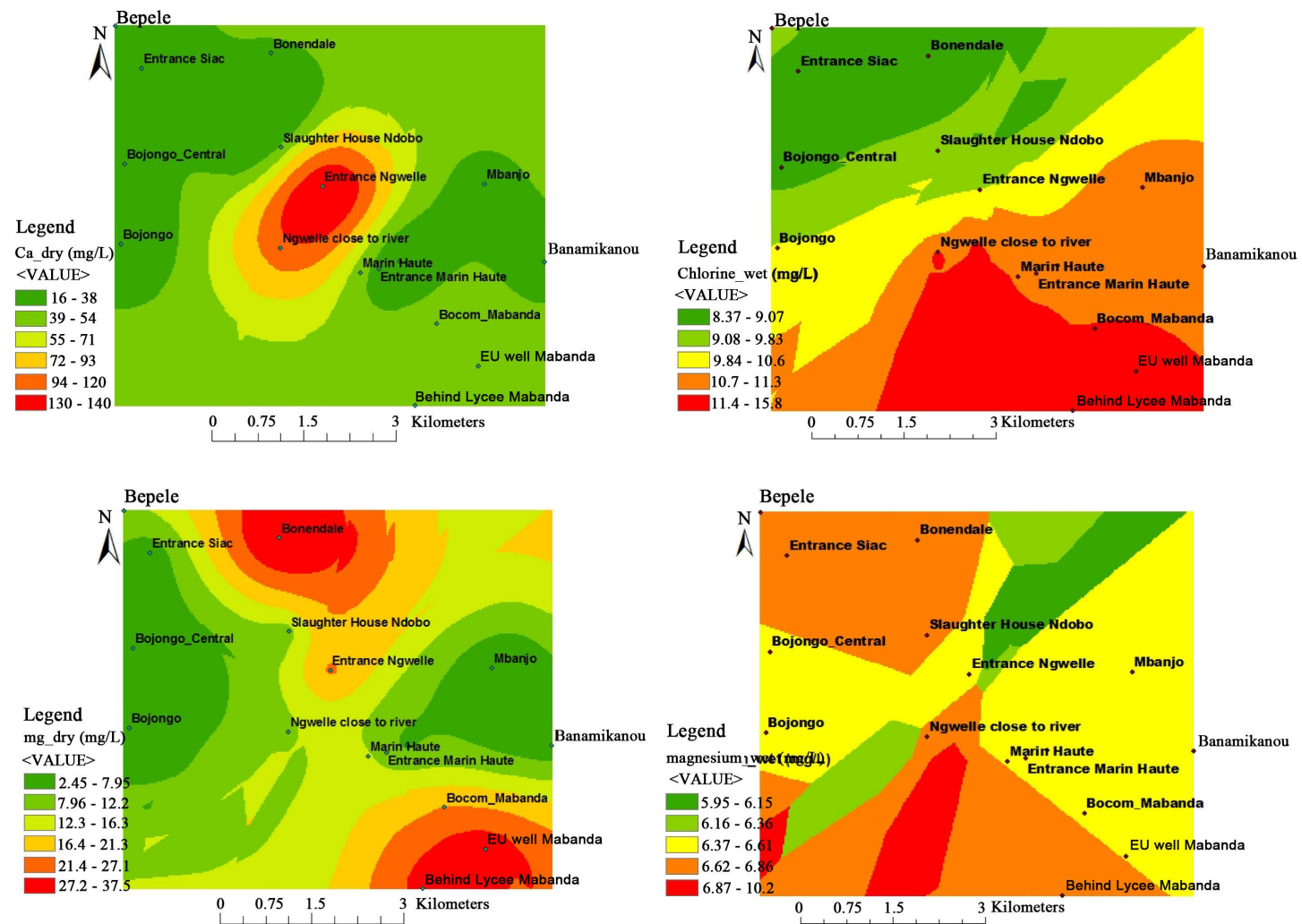

Figure 12. Output grids of spatial distribution of wet and dry season parameters (calcium and magnesium) for Douala IV. 
The dry and wet season $\mathrm{pH}$ ranges observed for this study are not within the range for good quality water. This could probably due to pollution resulting from urbanization, dense settlement and industrialization around the area. It could also lead to the release and deposition of gases that tend to lower the $\mathrm{pH}$. Reference [30] indicated low values of $\mathrm{pH}$ to the nearness of sampled sites to industrial zones.

The physical data of EC and TDS concentrations and the location of the impacted areas revealed that the South Eastern region, Central region and North Western region of Douala IV as the main points of entrance of saline contamination. Earlier studies [8] showed that water samples of this area are acidic with high values of EC and TDS. The results of this study indicate that SWI is occurring in the South Eastern region which is relatively close to the Gulf of Guinea. Thus, the presence of salt water indicators of the EU funded well Mabanda and the Well behind Lycee de Mabanda is likely the result of a combination of both saltwater intrusion from the Gulf of Guinea and surface contamination.

Reference [21], [31], and [32] indicate that, EC values are used as a guide to overall salinity. Values of EC are further influenced by certain ions (calcium, sodium, chlorine and sulphate). Thus, wet season high values of calcium for this study might be due to domestic waste water inputs and leached soils and rocks. These high values will consequently alter the salinity levels of the water as are observed from the high EC values of $850 \mu \mathrm{S} / \mathrm{cm}$ wet seasons which is higher than the $750 \mu \mathrm{S} / \mathrm{cm}$ value stipulated by WHO. Dry season EC values of $1790 \mu \mathrm{S} / \mathrm{cm}$ (Figure 10) are outrageous and highlight the gradual spreading of saline contamination into fresh water aquifers of the area.

Another result of this study indicates that saline contamination may occur in the North Western region of the study, specifically at Bonjongo. Well water samples and iso-concentration maps revealed that these samples did not exhibit significant degradation of water quality due to SWI. However, the concentration of sodium is high probably due to an evaporation of well waters in the dry season. Since sodium ions influence EC values and serve like guide to salinity, it can be inferred that there might be a possible source of saline contamination from this area. Several authors have highlighted the fact that thematic taps of these nature revealing high values of water variables in an area which might not be a risk hazard to water sources but indicate the susceptibility of these areas to such hazards [16], [33] and [34]. These suggest that the well waters here are less vulnerable to saltwater contamination, but eminent inundation hazards of SLR might compromise fresh water resources from this front.

There is a huge spatial difference between the dry season and wet season water nitrate content, though the well water is not vulnerable to nitrate contamination. Reference [35] on the river Wouri indicated that nitrate contamination is not vulnerable. From the generated grid map, dry season highs are found in the Northern region of the study area while wet highs are found in the South Eastern region of the study area. Wet season highs might have resulted from contaminated water sources that infiltrate and move laterally towards that area or might 
simply have been washed to those areas during heavy down pour. Dry season highs could be indicative of the use of fertilizers at those points.

Maximum highs for dry and wet season values obtained from the study area for chlorine (Figure 11) falls in line with the recommended value by the World Health organization. However, the obtained value could eventually increase if inundation risks of SLR are experienced in this region. This is because impacts of SLR hazards have been highlighted to compromise the water quality of coastal aquifers [5], [26] and [36] [37] [38] [39] [40].

The location of major ions of calcium and sulphate are unique. High values of dry season calcium and wet season sulphate were observed at the same spot from the output grid maps (Figure 12). They were both observed at the Entrance Ngwelle. The maximum concentration values were observed to be decreasing from these centrally located areas to the surrounding areas. The presence of these high values might be as a result of breakdown of the bedrock materials as illustrated by the output grid maps indicating that the materials are coming from the same source. Similar studies [26], [41] and [42] have indicated the breakdown of bedrock materials in the soil. Paradoxically, wet season calcium and dry season sulphate locations are at variance with the corresponding dry season calcium and wet season sulphate. This could be due to weathering and washing away of this calcium during the wet period. The trend of this variable movement appears to be in the South Eastern direction.

\section{Conclusions}

The spatial-temporal distribution analysis of well water quality for Douala IV with GIS geostatistical techniques was assessed. As sampling from every possible location is not economical, the interpolation technique (ordinary Kriging) played a vital role to predict the values from unmeasured locations. Laboratory analysis of water quality parameters (Table 1 and Table 2 ) showed that samples of water temperature, $\mathrm{pH}, \mathrm{EC}, \mathrm{TDS}, \mathrm{DO}$, calcium, magnesium did not conform to the limits put in place by WHO [8] water temperature: $15^{\circ} \mathrm{C} ; \mathrm{pH}: 6.5-8.5$; EC: $750 \mu \mathrm{S} / \mathrm{cm}$; TDS: $500 \mathrm{mg} / \mathrm{L}$, DO: $5 \mathrm{mg} / \mathrm{L}, \mathrm{Ca}^{2+}: 75 \mathrm{mg} / \mathrm{L}$ and $\mathrm{Mg}^{2+}: 30 \mathrm{mg} / \mathrm{l}$.

From the thematic maps obtained, the study shows that four possible points of contamination are found in this region.

1) The South Eastern part (represented by EU funded well at Mabanda, Behind Lycee Mabanda) of the study area, where highs of EC, Salinity, and TDS are seen to be spreading inland to fresh water aquifers and

2) Sodium and to a lesser extent potassium and bicarbonates contamination from the South Western region (Bojongo) of the study area

3) Calcium and sulphate contamination is observed at the Central Region (represented by the slaughter house Ndobo and Entrance Ngwelle) of the study area, indicating the presence of rocks that are being weathered that could be contributing to the high values of these ions observed. The dissolution of these rocks can eventually spread to the surrounding areas. 
4) Areas of very low DO values which are usually influenced by $\mathrm{pH}$ and salinity values are highlighted from their corresponding output grid maps.

SWI is actually taking place in the region on two fronts: The South Eastern and North Western front. However, the North Western Front is not as high as the South Eastern front of the study area. With the eminent two fronts of saline contamination evident in the area, ground water resources quality which the resource limited inhabitants of the area depend on could be compromised. This is because SLR hazards of inundation could bring in more salt water on the two fronts. This will completely render fresh water resources in the areas to be contaminated with the possibility of an increase in the area contaminated. Thus, areas of highs if not properly managed can affect the surrounding areas and pollute the entire water resources of the region.

The combination of tools used for the purpose of this study provided an opportunity to assemble, standardize, and analyse scientific data that comes from a variety of sources. Such data could be made available to others who may be able to continue with further research studies and/or use the information for improved groundwater management strategies in the area. These thematic maps of well water quality parameters shown can be beneficial to the Douala IV City Council authority for the effective management and monitoring of groundwater resources in the area.

\section{Conflicts of Interest}

The authors declare no conflicts of interest regarding the publication of this paper.

\section{References}

[1] Gleick, P.H. (1998) The World's Water: The Biennial Report on Freshwater Resources. Island Press, Washington DC, 7-14.

[2] Fonteh, M., Esteves, L.S. and Gehrels, W.R. (2009) Mapping and Valuations of Ecosystems and Economic Activities along the Coasts of Cameroon: Implications of Future Sea Level Rise. Coastline Reports, 13, 47-63.

[3] Ndenecho, E.N. and Fonteh, M.L. (2012) Freshwater and Coastal Resource Management in Cameroon: Building Resistance and Resilience to Climate Change. Agwecams Printers Bamenda, Bamenda, 328 pp.

[4] Zghibi, A., Tarhouni, J. and Zouhri, L. (2013) Assessment of Seawater Intrusion and Nitrate Contamination on the Groundwater Quality in the Korba Coastal Plain of Cap-Bon (North-East of Tunisia). Journal of African Earth Sciences, 87, 1-12. https://doi.org/10.1016/j.jafrearsci.2013.07.009

[5] Guishan, Y. (1992) Impacts of Future Sea Level Rise on Salt Water Intrusion in the Changjiang River Estuary. Chinese Geographical Science, 2, 30-41. https://doi.org/10.1007/BF02664544

[6] Emmanuel, B.E. and Chukwu, L.O. (2010) Spatial Distribution of Saline Water and Possible Sources of Intrusion into a Tropical Freshwater Lagoon and the Transitional Effects on the Lacustrine Ichthyofaunal Diversity. African Journal of Environmental Science and Technology, 4, 480-491. 
[7] Murgulet, D. and Tick, G.R. (2008) Assessing the Extent of Saltwater Intrusion in the Aquifer System of Southern Baldwin County, Alabama. 20 th Salt Water Intrusion Meeting, Naples, FL, 23-27 June 2008, 159-162.

[8] Fonteh, M.L., Fonkou, T., Fonteh, M.F., Njoyim, E.B.T. and Lambi, C.M. (2017) Spatial Variability and Contamination Levels of fresh Water Resources by Saline Intrusion in the Coastal Low Lying Areas of the Douala Metropolis-Cameroon. Journal of Water Resource and Protection, 9, 215-237. https://doi.org/10.4236/jwarp.2017.92015

[9] APHA/AWWA/WEP (2005) Standard Methods for the Examination of Water and Wastewater. 21st Edition, APHA, AWWA, and WEF.

[10] Domenico, P.A. and Schwartz, F.W. (1990) Physical and Chemical Hydrogeology. John Wiley and Sons, New York, 485-497.

[11] Hengl, T. (2007) Practical Guide to Geostatistical Mapping of Environmental Variables. Joint Research Center Institute for Environmental Sustainability. http://eusoils.jrc.it/ESDB_Archive/eusoils_docs/other/EUR22904en.pdf

[12] Bratt, S. and Booth, B. (2002) Using ArcGIS 3D Analyst. GIS by ESRI. New York, $260 \mathrm{pp}$.

[13] Baddeley, A. and Turner, R. (2004) Spatstat: An R Package for Analyzing Spatial Point Patterns. Journal of Statistical Software, 12, 18851.

http://www.jstatsoft.org/v12/i06 https://doi.org/10.18637/jss.v012.i06

[14] Clark, I. (1979) Practical Geostatistics. Applied Science Publishers Ltd., London, 129 pp.

[15] Davis, J.C. (1986) Statistics and Data Analysis in Geology. 2nd Edition, John Wiley, New York, 646 pp.

[16] Munna, G.M., Numan-Al-Kibriya, H.A., Nury, S.I. and Rahman, H. (2015) Spatial Distribution Analysis and Mapping of Groundwater Quality Parameters for the Sylhet City Corporation (SCC) Area Using GIS. Hydrology, 3, 1-10. https://doi.org/10.11648/j.hyd.20150301.11

[17] WHO (2004) Guidelines for Drinking-Water Quality. 3rd Edition, WHO, Geneva, Switzerland, $514 \mathrm{pp}$.

[18] Chapman, D. (1996) Water Quality Assessments: A Guide to the Use of Biota, Sediments and Water in Environmental Monitoring. UNESCO/WHO/UNEP, Cambridge, Great Britain, 609 pp. https://doi.org/10.4324/NOE0419216001

[19] Magha, A., Awah, M.T., Nono, G.D.K., Wotchoko, P., Tabot, M.A. and Kabeyene, V.K. (2015) Physico-Chemical and Bacteriological Characterization of Spring and Well Water in Bamenda III (NW Region, Cameroon). American Journal of Environmental Protection, 10, 20. https://doi.org/10.11648/j.ajep.20150403.17

[20] Cairncross, S. and Feachem, R.G. (1983) Environmental Health Engineering in the Tropics: An Introductory Text. John Wiley and Sons, London, $283 \mathrm{pp}$.

[21] Freeze, R.A. and Cherry, J.A. (1979) Groundwater. 2nd Edition, Prentice Hall, Eaglewood, Cliff, NJ, 604 pp.

[22] Lawson, E.O. (2011) Physico-Chemical Parameters and Heavy Metal Contents of Water from the Mangrove Swamps of Lagos Lagoon, Lagos, Nigeria. Advances in Biological Research, 5, 8-21. https://doi.org/10.3923/jfish.2010.36.43

[23] Mather, J.D. (1995) Groundwater Quality in Urban Developments. Groundwater Quality, 3, 157-158.

[24] Mehallis, M. (2004) Environmental Management and Water Quality and Quantity, 
in Water Interactions with Energy, Environment and Food and Agriculture. In: Donoso, M.C., Ed., Encyclopedia of Life Support Systems (EOLSS), Developed under the Auspices of the UNESCO, Eolss Publishers, Oxford, UK. http://www.eolss.net

[25] Sarath Prasanth, S.V., Magesh, N.S., Jitheshlal, K.V., Chandrasekar, N. and Gangadhar, K. (2012) Evaluation of Groundwater Quality and Its Suitability for Drinking and Agricultural Use in the Coastal Stretch of Alappuzha District, Kerala, India. Applied Water Science, 2, 165-175. https://doi.org/10.1007/s13201-012-0042-5

[26] Slama, F., Bouhlila, R. and Renard, P. (2010) Identification of Groundwater Salinization Sources Using Experimental, Multivariate Statistical Analysis and Numerical Modelling Tools: Case of Korba Coastal Aquifer (Tunisia). 38th IAH Congress, Groundwater Quality Sustainability, Krakow, 12-17 September 2010.

[27] van Wyk, J., Meissner, R. and Jacobs, H. (2004) Futre Challenges of Providing High-Quality Water, in Future Challenges of Providing High-Quality Water. In: van Wyk, J.-A., Jacobs, H. and Meissner, R., Eds., Encyclopedia of Life Support Systems (EOLSS), Developed under the Auspices of the UNESCO, Eolss Publishers, Oxford, UK. http://www.eolss.net

[28] Eneke, G.T., Ayonghe, S.N., Chandrasekharam, D., Ntchancho, R., Ako, A.A., Mouncherou, O.F. and Thambidurai, P. (2011) Controls on Groundwater Chemistry in a Highly Urbanised Coastal Area. International Journal of Environmental Research, 5, 475-490.

[29] UNEP/GEMS (2008) United Nations Environment Programme Global Environment Monitoring System/Water Programme. Water Quality for Ecosystem and Human Health, 2nd Edition, 130 pp.

[30] Tening, A.S., Chuyong, G.B., Asongwe, G.A., Fonge, B.A., Lifongo, L.L., Mvondo-Ze, A.D., Che, V.B. and Suh, C.E. (2013) Contribution of Some Water Bodies and the Role of Soils in the Physicochemical Enrichment of the Douala-Edeamangrove Ecosystem. African Journal of Environmental Science and Technology, 7, 336-349.

[31] Hem, J.D. (1989) Study and Interpretation of the Chemical Characteristics of Natural Water. Water Supply Paper 2254, 3rd Edition, US Geological Survey, Washington DC, $263 \mathrm{pp}$

[32] Geake, A.K., Foster, S.S.D., Nakamatsu, N., Valenzuela, C.F. and Valverde, M.L. (1986) Groundwater Recharge and Pollution Mechanisms in Urban Aquifers of Arid Regions. Hydrogeological Report 86/11, British Geological Survey, Wallingford, $\mathrm{UK}, 55 \mathrm{pp}$.

[33] Pendleton, E.A., Barras, J.A., Williams, S.J. and Twichell, D.C. (2010) Coastal Vulnerability Assessment of the Northern Gulf of Mexico to Sea-Level Rise and Coastal Change. U.S. Geological Survey Open-File Report 2010-1146.

http://pubs.usgs.gov/of/2010/1146/ https://doi.org/10.3133/ofr20101146

[34] Sankaran, S., Sonkamble, S., Krishnakumar, K. and Monda, N.C. (2012) Integrated Approach for Demarcating Subsurface Pollution and Saline Water Intrusion Zones in SIPCOT Area: A Case Study from Cuddalore in Southern India. Environmental Monitoring and Assessment, 184, 5121-5138.

https://doi.org/10.1007/s10661-011-2327-9

[35] Tening, A.S., Chuyong, G.B., Asongwe, G.A., Fonge, B.A., Lifongo, L.L. and Tandia, B.K. (2013) Nitrate and Ammonium Levels of Some Water Bodies and Their Interaction with Some Selected Properties of Soils in Douala Metropolis, Cameroon. African Journal of Environmental Science and Technology, 7, 648-656. 
[36] Terzic, J., Markovic, T. and Pekas, Z. (2008) Influence of Sea-Water Intrusion and Agricultural Production on the Blato Aquifer, Island of Korcula, Croatia. Environmental Geology, 54, 719-729. https://doi.org/10.1007/s00254-007-0841-4

[37] Pulido-Leboeuf, P. (2004) Seawater Intrusion and Associated Processes in a Small Complex Aquifer (Castell de Ferro, Spain). Applied Geochemistry, 19, 1517-1527. https://doi.org/10.1016/j.apgeochem.2004.02.004

[38] Milnes, E., Meilhac, C., Yeo, D., Renard, P., Hunkeler, D., Schnegg, P. and Bourret, F. (2006) Hydrogeochemical and Hydrogeological Investigationin the Akrotiri Aquifer: Identification of Multiple Salnisation Processes and Implementation Criteria for Monitoring Networks. SWIM-SWICA.

[39] Zghibi, A., Zouhri, L., Tarhouni, J. and Kouzana, L. (2012) Groundwater Mineralisation Processes in Mediterranean Semiarid Systems (Cap-Bon, North East of Tunisia): Hydrogeological and Geochemical Approaches. Hydrological Processe, 27, 3227-3239. http://wileyonlinelibrary.com https://doi.org/10.1002/hyp.9456

[40] Kouzana, L., Ben Mammou, A. and Sfar Felfoul, M. (2009) Seawater Intrusion and Associated Processes: Case of the Korba Aquifer (Cap-Bon, Tunisia). Surface Geosciences (Hydrology-Hydrogeology). Comptes Rendus Geoscience, 341, 21-35. https://doi.org/10.1016/j.crte.2008.09.008

[41] Ako, A.A., Shimada, J., Hosono, T., Ichiyanagi, K., Nkeng, G.E., Fantong, W.Y., Eyong, G.E.T. and Roger, N.N. (2011) Evaluation of Groundwater Quality and Its Suitability for Dinking, Domestic, and Agricultural Uses in the Banana Plain (Mbanga, Njombe, Penja) of the Cameroon Volcanic Line. Environmental Geochemistry and Health, 33, 559-575. https://doi.org/10.1007/s10653-010-9371-1

[42] Oyedele, K.F. and Momoh, E.I. (2009) Evaluation of Sea Water Intrusion in Freshwater Aquifers in a Lagoon Coast: A Case Study of the University of Lagos Lagoon, Akoka, Nigeria. New York Science Journal, 2, 32-42. 